\title{
Antibodies toward infliximab are associated with low infliximab concentration at treatment initiation and poor infliximab maintenance in rheumatic diseases
}

Emilie Ducourau ${ }^{1,2+}$, Denis Mulleman ${ }^{1,2^{*}+}$, Gilles Paintaud ${ }^{1,3}$, Delphine Chu Miow Lin ${ }^{1,2}$, Francine Lauféron ${ }^{1,2}$, David Ternant ${ }^{1,3}$, Hervé Watier ${ }^{1,4}$ and Philippe Goupille $e^{1,2}$

\begin{abstract}
Introduction: A proportion of patients receiving infliximab have antibodies toward infliximab (ATI), which are associated with increased risk of infusion reaction and reduced response to treatment. We studied the association of infliximab concentration at treatment initiation and development of ATI as well as the association of the presence of ATI and maintenance of infliximab.

Methods: All patients with rheumatoid arthritis (RA) or spondyloarthritis (SpA) receiving infliximab beginning in December 2005 were retrospectively followed until January 2009 or until infliximab discontinuation. Trough serum infliximab and ATI concentrations were measured at each visit. The patients were separated into two groups: ATI pos if ATI were detected at least once during the follow-up period and ATI neg otherwise. Repeated measures analysis of variance was used to study the association of infliximab concentration at treatment initiation and the development of ATI. Maintenance of infliximab in the two groups was studied by using Kaplan-Meier curves.

Results: We included 108 patients: 17 with RA and 91 with SpA. ATI were detected in 21 patients (19\%). The median time to ATI detection after initiation of infliximab was 3.7 months (1.7 to 26.0 months). For both RA and SpA patients, trough infliximab concentration during the initiation period was significantly lower for ATI pos than $\mathrm{ATI}_{\text {neg }}$ patients. RA patients showed maintenance of infliximab at a median of 19.5 months (5.0 to 31.0 months) and 12.0 months (2.0 to 24.0 months) for $A T I_{\text {neg }}$ and $A T I_{\text {pos }}$ groups, respectively $(P=0.08)$. SpA patients showed infliximab maintenance at a median of 16.0 months (3.0 to 34.0 months) and 9.5 months (3.0 to 39.0 months) for $A T I_{\text {neg }}$ and $A T I_{\text {pos }}$ groups, respectively $(P=0.20)$. Among SpA patients, those who were being treated concomitantly with methotrexate had a lower risk of developing ATI than patients not taking methotrexate (0 of 14 patients (0\%) vs. 25 of 77 patients (32\%); $P=0.03$ ).
\end{abstract}

Conclusions: High concentrations of infliximab during treatment initiation reduce the development of ATI, and the absence of ATI may be associated with prolonged maintenance of infliximab. Thus, trough serum infliximab concentration should be monitored early in patients with rheumatic diseases.

\footnotetext{
* Correspondence: mulleman@med.univ-tours.fr

† Contributed equally

'Université François Rabelais de Tours, Centre National de la Recherche

Scientifique UMR 6239 GICC (Génétique Immunothérapie Chimie et Cancer),

3 rue des Tanneurs, F-37041 Tours Cedex 1, France

Full list of author information is available at the end of the article
} 


\section{Introduction}

Infliximab, a chimeric $\mathrm{mAb}$ targeting $\mathrm{TNF} \alpha$, is used to treat rheumatoid arthritis (RA), spondyloarthritis (SpA) and inflammatory bowel diseases. Its efficacy and safety have been evaluated in selected patients in pivotal clinical trials [1-3], but predictive factors regarding its maintenance in the postmarketing clinical setting have not been reported. Because of its immunogenicity, infliximab is responsible for the development of antibodies toward infliximab (ATI), which is associated with increased risk of treatment failure. In RA, the development of ATI is inversely proportional to the dosage of infliximab [1], and low trough serum infliximab concentration 1.5 months after initiation is associated with the development of ATI [4]. Moreover, ATI are associated with increased risk of infusion reactions and decreased response to infliximab $[4,5]$. Trough serum infliximab concentration has been measured in SpA in only two studies. De Vries et al. [6] found that treatment failure is associated with low serum concentration and that the development of ATI is associated with undetectable trough infliximab concentration, reduced response to treatment and increased risk of infusion reactions. In contrast, Krzysiek et al. [7] did not find any association of trough infliximab concentration and response to treatment. Therefore, the relationships among infliximab concentration, development of ATI and response to treatment are less clear in SpA than in RA. Moreover, no study has focused on the temporal relationship between trough infliximab concentration and development of ATI.

We studied the association of trough serum infliximab concentration measured at treatment initiation and the development of ATI in a retrospective cohort with inflammatory rheumatic diseases. We also studied the association of ATI, infusion-related reactions and maintenance of infliximab.

\section{Materials and methods \\ Patients}

Patients with RA and patients with SpA whose infliximab treatment was started between December 2005 and January 2009 or until infliximab discontinuation were retrospectively included. Demographic characteristics, mean disease duration and concomitant treatment with methotrexate (MTX) or prednisone were recorded before infliximab initiation. RA patients received $3 \mathrm{mg} /$ $\mathrm{kg}$ infliximab intravenously (rounded in the 100-mg vial) at weeks $0,2,6$ and 14 and every 8 weeks thereafter, and $\mathrm{SpA}$ patients received $5 \mathrm{mg} / \mathrm{kg}$ infliximab (rounded in the 100-mg vial) at weeks $0,2,6$ and 12 and every 6 weeks thereafter. The time and circumstances of discontinuation were recorded. The treatment protocol was in accordance with the guidelines of the French Society of Rheumatology for the use of infliximab [8,9]. Ethical approval and informed consent were not sought in this retrospective analysis of routine patients, which is in accordance with institutional guidelines.

\section{Clinical measurements}

Before proceeding with the first infusion (baseline) and at each subsequent infusion, patients were asked about any adverse events since the previous visit and underwent a physical examination and urine analysis to rule out any concomitant infection. At each visit, the Disease Activity Score in 28 joints was measured for RA patients and the Bath Ankylosing Spondylitis Disease Activity Index (BASDAI) was used to assess disease activity in SpA patients. Blood samples were obtained 48 hours before each infusion for routine measurement of erythrocyte sedimentation rate (ESR) and C-reactive protein level (CRP).

\section{Infliximab serum and ATI concentrations}

Serum samples were obtained just before each infusion for infliximab concentration measurement and ATI detection within the framework of routine therapeutic drug monitoring. The samples were not drawn specifically for this study, which was performed retrospectively. Infliximab concentrations were measured by ELISA as described previously [10]. Serum concentration of ATI was measured by double-antigen ELISA on the basis of capture by infliximab-coated microplates and detection by peroxidase-conjugated infliximab [11]. This assay was standardised by the use of a mouse mAb against human immunoglobulin G. The positive threshold of detection was $0.07 \mathrm{mg} / \mathrm{L}$. Because of the interference of circulating infliximab, only sera with infliximab concentration $<2$ $\mathrm{mg} / \mathrm{L}$ were tested. Patients were separated into two groups: $\mathrm{ATI}_{\mathrm{pos}}$ if ATI were detected at least once during follow-up and $\mathrm{ATI}_{\text {neg }}$ otherwise.

\section{Dose adjustment}

Infliximab dose could be adapted after the fourth infusion. The decision to increase, decrease or discontinue infliximab took into account the disease activity assessment on the one hand and infliximab trough concentration on the other hand. The principle underlying this drug monitoring procedure was previously described [12].

\section{Statistical analysis}

Baseline characteristics of $\mathrm{ATI}_{\text {pos }}$ and $\mathrm{ATI}_{\text {neg groups }}$ were compared by using Student's $t$-test or a $\chi^{2}$ test. Repeated measures analysis of variance was used to study the association of infliximab concentration during 
treatment initiation and the development of ATI. Maintenance of infliximab was studied by using KaplanMeier curves, and groups were compared by using a logrank test. Statistical analysis involved use of $\mathrm{R}$ version 2.7.2 software [13]. $P<0.05$ was considered statistically significant. Results are presented as medians (full ranges) unless otherwise stated.

\section{Results}

\section{Baseline characteristics of patients}

We included 108 patients: 17 with RA and 91 with SpA. ATI, which were undetectable in all patients before the initiation of infliximab therapy, were detected in 21 patients ( 7 with RA and 14 with SpA) during follow-up. The proportion of $\mathrm{ATI}_{\text {pos }}$ patients was higher among those with RA than in patients with SpA ( $41 \%$ vs. $15 \%$, respectively; $P=0.03$ ). The baseline characteristics of the patients are given in Table 1 . The $\mathrm{ATI}_{\text {pos }}$ and $\mathrm{ATI}_{\text {neg }}$ patients did not differ with regard to age, body mass index, concomitant treatment with prednisone or ESR or CRP level. For SpA patients, disease duration was longer, but not significantly so, for the $\mathrm{ATI}_{\text {pos }}$ group than for the $\mathrm{ATI}_{\text {neg }}$ group. Median time of ATI detection after initiation was 3.7 months (1.7 to 26.0 months). For RA patients, the infliximab dose was lower, but not significantly so, for the $\mathrm{ATI}_{\text {pos }}$ patients than for the $\mathrm{ATI}_{\text {neg }}$ patients (Table 1 and Figure 1). For SpA patients, concomitant MTX treatment was lower for $\mathrm{ATI}_{\text {pos }}$ than for $\mathrm{ATI}_{\text {neg }}$ patients $(0(0 \%)$ of 14 vs. 25 (32\%) of 77 , respectively; $P=0.03$ ) (Tables 1 and 2).

\section{Association of initial infliximab concentration and development of ATI}

Trough serum infliximab concentration during treatment initiation (weeks 2 to 14) was lower for $\mathrm{ATI}_{\text {pos }}$ patients than for $\mathrm{ATI}_{\text {neg }}$ patients for both diseases, with the difference being significant as early as week 2 (Table 3
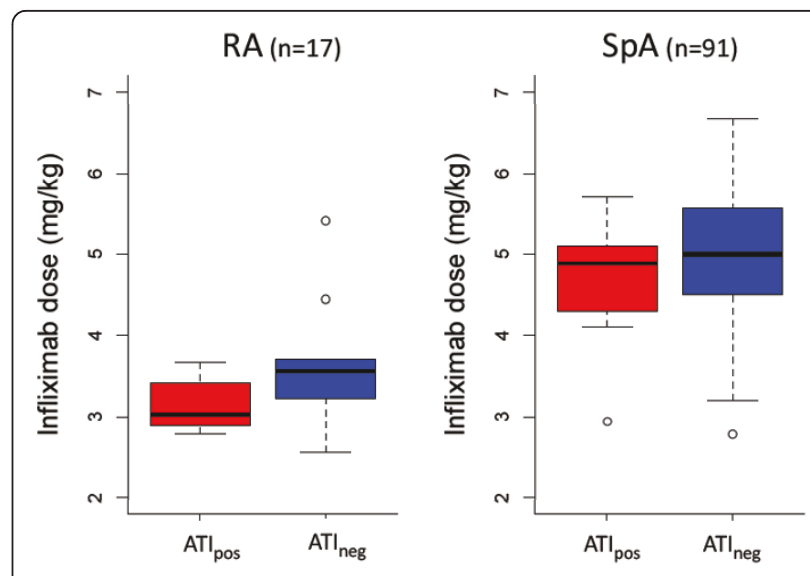

Figure 1 Initial infliximab dose for patients positive and negative for antibodies toward infliximab (ATI $I_{\text {pos }}$ and $\mathrm{ATI}_{\text {negr }}$ respectively). Box plots show the medians and interquartile ranges, and the whisker plots represent the 95th percentiles. Two patients in the RA subgroup (open circles) received $5 \mathrm{mg} / \mathrm{kg}$ infliximab at initiation because they were initially suspected of having psoriatic arthritis. During follow-up, anticitrullinated protein antibodies were detected in both patients, which explains their placement in the RA subgroup. Two patients with SpA (open circles) received $3 \mathrm{mg} / \mathrm{kg}$ infliximab at initiation because they had a peripheral form of the disease and were therefore misclassified as having RA. ATI: antibodies toward infliximab; ATI pos: ATI detected at least once during follow-up; ATI neg: ATI not detected; RA: rheumatoid arthritis; SpA: spondyloarthritis.

Table 2 Development of ATI by MTX treatment in RA and SpA patients ${ }^{a}$

\begin{tabular}{lcccccc}
\hline & \multicolumn{3}{c}{$\mathrm{RA}(\boldsymbol{n}=\mathbf{1 7})$} & \multicolumn{3}{c}{$\mathrm{SpA}(\boldsymbol{n}=\mathbf{9 1})$} \\
\cline { 2 - 7 } MTX treatment & $\mathrm{ATI}_{\text {pos }}$ & $\mathrm{ATI}_{\text {neg }}$ & $\boldsymbol{P}$ value & $\mathrm{ATI}_{\text {pos }}$ & $\mathrm{ATI}_{\text {neg }}$ & $\boldsymbol{P}$ value \\
\hline MTX+ & 3 & 6 & & 0 & 25 & \\
MTX- & 4 & 4 & 0.8 & 14 & 52 & 0.03 \\
\hline
\end{tabular}

${ }^{a}$ ATI: antibodies toward infliximab; $\mathrm{ATI}_{\text {pos }}$ : ATI detected at least once during follow-up; $\mathrm{ATI}_{\text {neg: }}$ ATI not detected; RA: rheumatoid arthritis; SpA:

spondyloarthritis; MTX: methotrexate. Data represent number of patients in each category.

Table 1 Baseline characteristics of the patients ${ }^{a}$

\begin{tabular}{|c|c|c|c|c|c|c|}
\hline \multirow[b]{2}{*}{ Characteristics } & \multicolumn{3}{|c|}{$\mathrm{RA}(n=17)$} & \multicolumn{3}{|c|}{$\operatorname{SpA}(n=91)$} \\
\hline & $\operatorname{ATI}_{\text {pos }}(n=7)$ & $\operatorname{ATI}_{\text {neg }}(n=10)$ & $P$ value & $\operatorname{ATI}_{\text {pos }}(n=14)$ & $\mathrm{ATI}_{\text {neg }}(n=77)$ & $P$ value \\
\hline Age, years & 49 (28 to 65$)$ & 47 (36 to 64$)$ & 0.7 & 47 (36 to 73 ) & 44 (14 to 76$)$ & 0.2 \\
\hline Body mass index, $\mathrm{kg} / \mathrm{m}^{2}$ & 25.9 (20.2 to 34.8$)$ & 23.5 (16.4 to 34.6$)$ & 0.5 & $24.8(17.5$ to 32.8$)$ & 26.1 (15.8 to 45.8$)$ & 0.1 \\
\hline Disease duration, years & $6.0(1$ to 12$)$ & 10 (2 to 30$)$ & 0.07 & 8.9 (0 to 24$)$ & 5 (0 to 24$)$ & 0.3 \\
\hline Infliximab dose, mg/kg & $3.0(2.8$ to 3.7$)$ & 3.6 (2.6 to 5.4$)$ & 0.09 & 4.9 (2.9 to 5.7$)$ & 5.0 (2.8 to 6.7$)$ & 0.4 \\
\hline \multicolumn{7}{|l|}{ Concomitant treatments } \\
\hline MTX, $n(\%)$ & $3(43)$ & $6(60)$ & 0.8 & $0(0)$ & $25(32)$ & 0.03 \\
\hline Prednisone, $n(\%)$ & $4(57)$ & $8(80)$ & 0.6 & $2(14)$ & $12(16)$ & 0.8 \\
\hline ESR, mm/hour & 14 (7 to 58$)$ & 24 (2 to 114$)$ & 0.5 & 8 (2 to 54$)$ & 10 (1 to 89$)$ & 0.6 \\
\hline CRP, mg/L & 10 (3 to 81$)$ & 16 (3 to 124$)$ & 0.9 & $3(1$ to 72$)$ & $5(1$ to 74$)$ & 0.9 \\
\hline
\end{tabular}

aTI: antibodies toward infliximab; ATI ${ }_{\text {pos: }}$ ATI detected at least once during follow-up; ATI neg: ATI not detected; RA: rheumatoid arthritis; SpA: spondyloarthritis; MTX: methotrexate; ESR: erythrocyte sedimentation rate; CRP: C-reactive protein. Results are given as medians (ranges) unless otherwise indicated. 


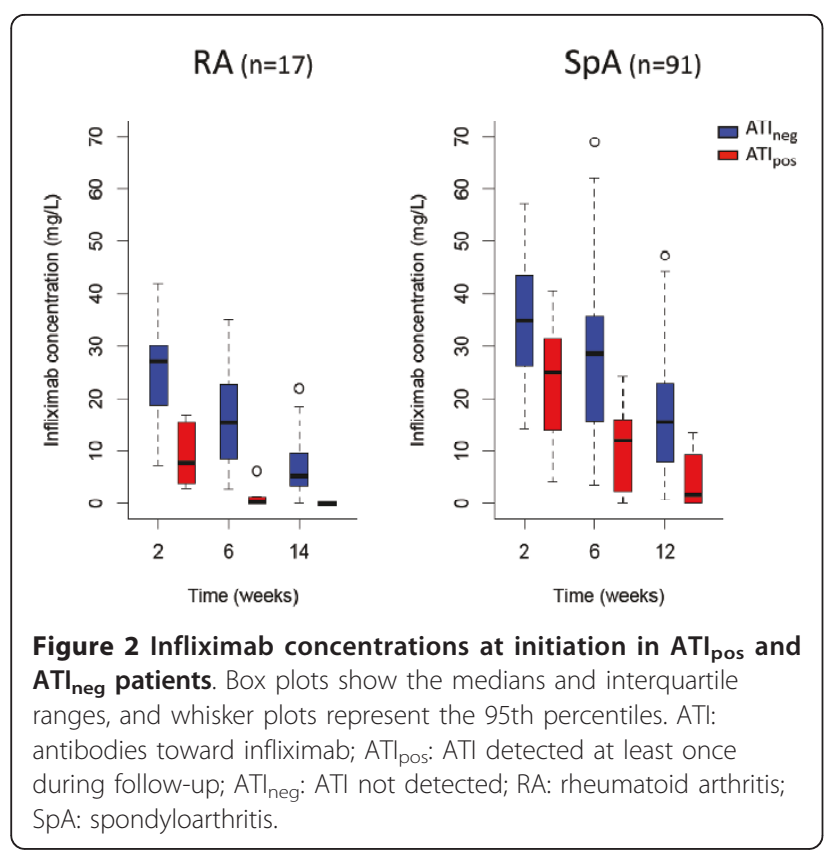

and Figure 2). For 8 of the $21 \mathrm{ATI}_{\text {pos }}$ patients, therapy was discontinued because of concomitant infection or surgery, and ATI developed after infliximab therapy was resumed.

Association of ATI, infusion reactions and maintenance of infliximab

Among $\mathrm{ATI}_{\text {pos }}$ patients, 11 (52\%) had at least one infusion-related reaction, as compared with only $1(1 \%)$ in the $\mathrm{ATI}_{\text {neg }}$ group. The median interval between ATI detection and infusion-related reactions was 42 days (0 to 702 days). These infusion-related reactions were rashes, hyperthermia, chills, Quincke's oedema and tachycardia. Among the $11 \mathrm{ATI}_{\text {pos }}$ patients who had a reaction to infusion, 4 required intravenous corticosteroids and intravenous antihistamines, and 2 required only oral antihistamines. One patient developed Guillain-Barré syndrome that partially improved after polyvalent immunoglobulin treatment. In four patients, no treatment was given.

Eighteen $(86 \%)$ of the $\mathrm{ATI}_{\text {pos }}$ patients and forty-one (47\%) of the $\mathrm{ATI}_{\text {neg }}$ patients discontinued infliximab during follow-up. Events leading to treatment withdrawal significantly differed between the two groups $(P<$ 0.001). In half of the $18 \mathrm{ATI}_{\text {pos }}$ patients, treatment was stopped because of infusion-related reactions, whereas in $31(76 \%)$ of the $41 \mathrm{ATI}_{\text {neg }}$ patients treatment was stopped because of treatment failure (Table 4). Infliximab was maintained longer, but not significantly so, in $\mathrm{ATI}_{\text {neg }}$ patients than in $\mathrm{ATI}_{\text {pos }}$ patients for both diseases (Figure 3). ATI neg and $\mathrm{ATI}_{\text {pos }}$ patients with RA showed maintenance of infliximab at a median of 19.5 months (5.0 to 31.0 months) and 12.0 months (2.0 to 24.0 months), respectively $(P=$ 0.08). ATI neg and ATI pos patients with SpA showed maintenance of infliximab at a median of 16.0 months (3.0 to 34.0 months) and 9.5 months (3.0 to 39.0 months), respectively $(P=0.20)$.

\section{Association of trough infliximab concentration after treatment initiation and maintenance of infliximab}

The association of maintenance of infliximab with infliximab concentration after treatment initiation is shown in Figure 4. RA patients whose trough infliximab concentration at week 14 was above the median (concentration > $3.2 \mathrm{mg} / \mathrm{L}$ ) and above the first quartile (concentration $>0.05 \mathrm{mg} / \mathrm{L}$ ) showed longer infliximab maintenance than other patients, although not significantly so (logrank $=0.06$ and 0.2 respectively). For SpA patients whose trough concentration at week 12 was above the median (concentration $>13.7 \mathrm{mg} / \mathrm{L}$ ), infliximab maintenance was no longer than that for other patients (logrank $=0.9)$. However, infliximab maintenance was longer for SpA patients with trough concentrations above the first quartile (concentration $>6.5 \mathrm{mg} /$ $\mathrm{L}$; logrank $=0.05)$ than for other patients.

\section{Discussion}

Our study demonstrates that low trough infliximab concentration during treatment initiation is predictive of immunisation against infliximab on the basis of the presence of ATI. Previous studies have reported an association of low infliximab concentration 1.5 months after initiation and the development of ATI [4]. We found that more patients with than without ATI had a low

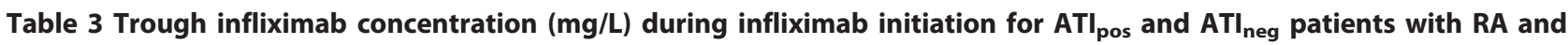
$\mathrm{SpA}^{\mathrm{a}}$

\begin{tabular}{|c|c|c|c|c|c|c|}
\hline \multirow[b]{2}{*}{ Time after infliximab initiation } & \multicolumn{3}{|c|}{$\mathrm{RA}(n=17)$} & \multicolumn{3}{|c|}{$\operatorname{SpA}(n=91)$} \\
\hline & $\mathrm{ATI}_{\text {pos }}(n=7)$ & $\mathrm{ATI}_{\text {neg }}(n=10)$ & $P$ value & $\mathrm{ATI}_{\text {pos }}(n=14)$ & $\mathrm{ATI}_{\text {neg }}(n=77)$ & $P$ value \\
\hline Week 2 & 7.7 (2.8 to 16.9$)$ & $27.2(7.1$ to 41.9$)$ & 0.002 & 25.0 (4.0 to 40.7$)$ & $35.8(14.3$ to 57.2$)$ & 0.003 \\
\hline Week 6 & 0.3 (0 to 6.2 ) & 15.4 (2.7 to 35.0$)$ & 0.001 & 11.9 (0 to 24.2$)$ & 29.5 (3.4 to 69.0$)$ & $<0.001$ \\
\hline Weeks 12 and 14 & 0 (0 to 0.03$)$ & $5.4(0$ to 21.9$)$ & 0.01 & 1.6 (0 to 13.5$)$ & 15.8 (0.7 to 47.3$)$ & $<0.001$ \\
\hline
\end{tabular}

${ }^{a}$ ATI: antibodies toward infliximab; ATI pos: ATI detected at least once during follow-up; ATI ${ }_{\text {neg: }}$ ATI not detected; RA: rheumatoid arthritis; SpA: spondyloarthritis. Results are given as medians (ranges). 
Table 4 Causes of infliximab discontinuation in ATI pos and $\mathrm{ATI}_{\text {neg }}$ patients ${ }^{\mathrm{a}}$

\begin{tabular}{lcc}
\hline Cause of discontinuation & $\mathbf{A T I}_{\text {pos }}(\boldsymbol{n}=\mathbf{1 8})$ & $\mathbf{A T I}_{\mathbf{n e g}}(\boldsymbol{n}=\mathbf{4 1 )}$ \\
\hline Treatment failure & $2(11 \%)$ & $23(56 \%)$ \\
$\quad$ Primary failure & $3(17 \%)$ & $8(20 \%)$ \\
$\quad$ Secondary failure & $9(50 \%)$ & $1(2 \%)$ \\
Infusion reactions & $1(5.5 \%)$ & $6(15 \%)$ \\
Adverse events & $1(5.5 \%)$ & $2(5 \%)$ \\
Other & $2(11 \%)$ & $1(2 \%)$ \\
Lost to follow-up &
\end{tabular}

${ }^{\mathrm{a} A T I}$ : antibodies toward infliximab; ATI pos: ATI detected at least once during follow-up; $\mathrm{ATI}_{\text {neg: }}$ ATI not detected. All data are number of patients (\%).

infliximab concentration as early as two weeks after their first infusion. Furthermore, in some cases, the development of ATI occurred after a temporary discontinuation of infliximab. Under a certain threshold concentration of infliximab, during treatment initiation or even after a 'therapeutic holiday', patients may be at high risk of immunisation against infliximab. ATI are known to increase infliximab clearance, as previously reported in SpA and inflammatory bowel diseases, and could explain the nonresponse or loss of response in some cases $[14,15]$. Our findings argue for early and continuous monitoring of serum concentrations of $\mathrm{mAb}$ in drugs such as infliximab. Further studies are needed to support this hypothesis before it can be applied in clinical practice.

As previously reported, development of ATI is associated with poor maintenance of infliximab $[5,6]$. We found that ATI developed during follow-up in $41 \%$ of RA patients and $15 \%$ of SpA patients receiving infliximab. Our results are similar to those of previous studies reporting ATI in $43 \%$ of RA patients and $29 \%$ of SpA patients in the first year of treatment $[5,6]$. We found that immunisation against infliximab occurs early after treatment initiation, because we detected ATI in half of the $\mathrm{ATI}_{\text {pos }}$ patients before a median of 3.7 months of treatment.

Immunogenicity of biopharmaceuticals is not restricted to chimeric $\mathrm{mAb}$. In a large cohort study of RA patients treated with adalimumab, a fully human mAb also targeting TNFa, Bartelds et al. [16] reported that 76 (28\%) of 272 patients developed antidrug antibodies (ADAs) after three years of treatment. In their study, ADAs were associated with a higher probability of treatment failure and drug discontinuation compared with ADA-negative patients. Immunisation appeared soon after treatment started: $67 \%$ of cases were detected during the first 28 weeks of therapy. The median time until detection of ATI in our study was 3.7 months, which is in good agreement with the results of the study by Bartelds et al. [16].

The development of ATI was also associated with increased risk of infusion reactions, as already reported [4-6]. In our experience, half of $\mathrm{ATI}_{\text {pos }}$ patients experience such reactions, often soon after the detection of ATI, which leads to infliximab discontinuation.

Of note, because of drug intolerance, only $53 \%$ of our RA patients received MTX with infliximab. This situation may account for the rather high frequency of immunisation observed in our study. The role of MTX in preventing ATI formation in RA was suspected by Maini et al. [1] and Bendtzen et al. [4]. In our study, ATI developed less often, although not significantly so, in RA patients receiving infliximab and MTX than in those receiving infliximab alone, but the small number of patients $(n=17)$ prevents us from drawing any
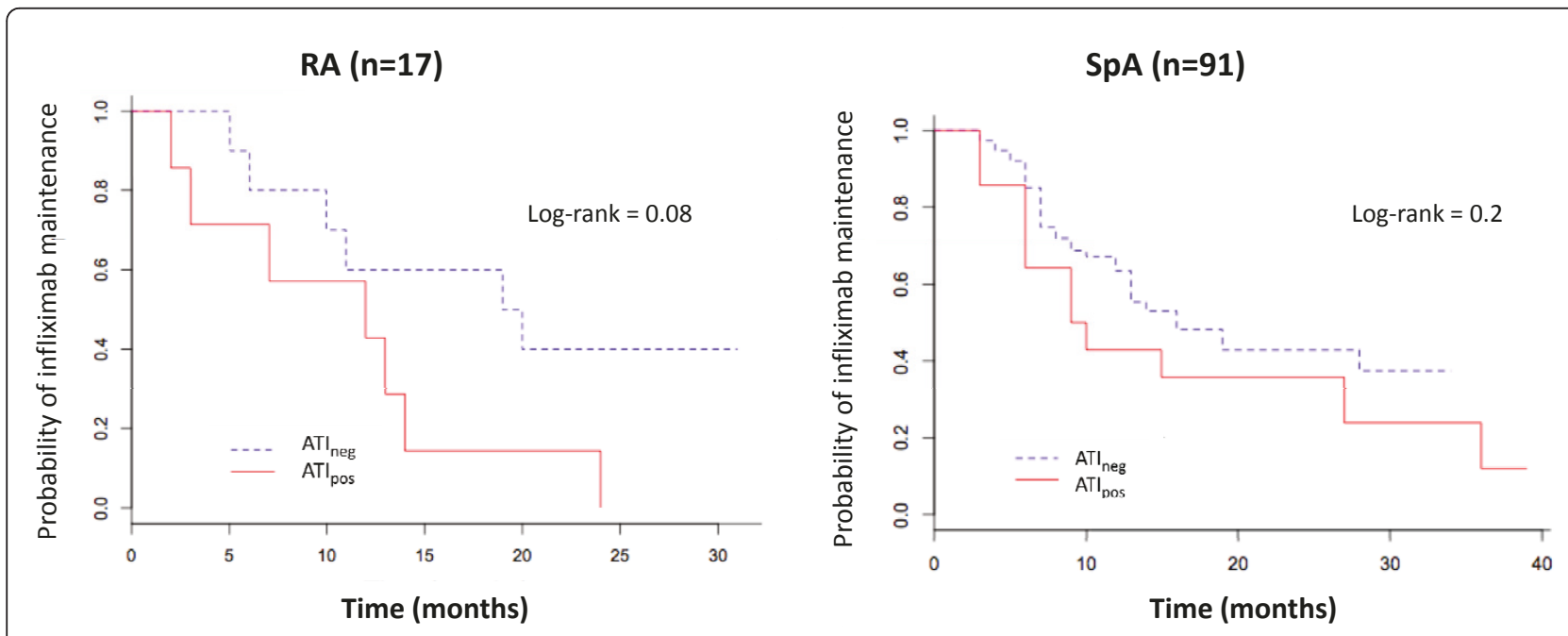

Figure 3 Infliximab maintenance according to ATI status in RA and SpA patients. ATI: antibodies toward infliximab; ATI pos: ATI detected at least once during follow-up; ATI neg: ATI not detected. 
a)

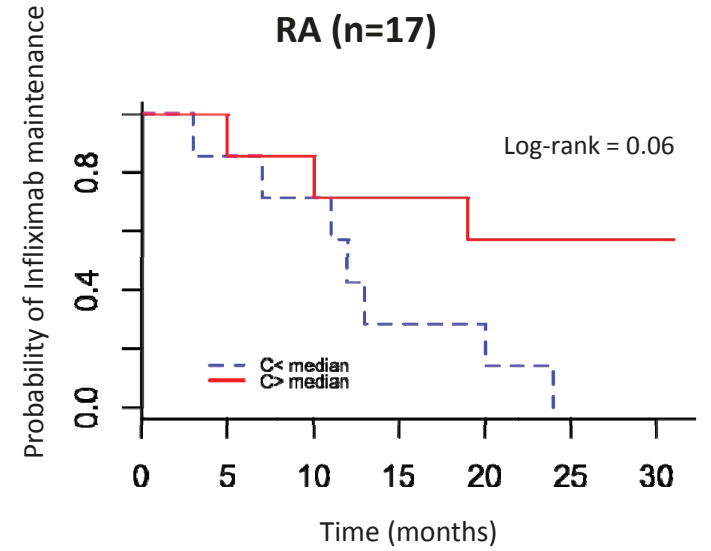

b)

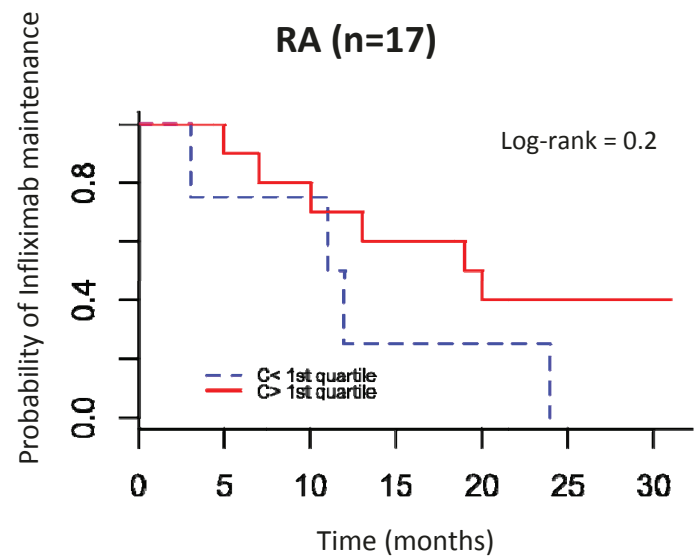

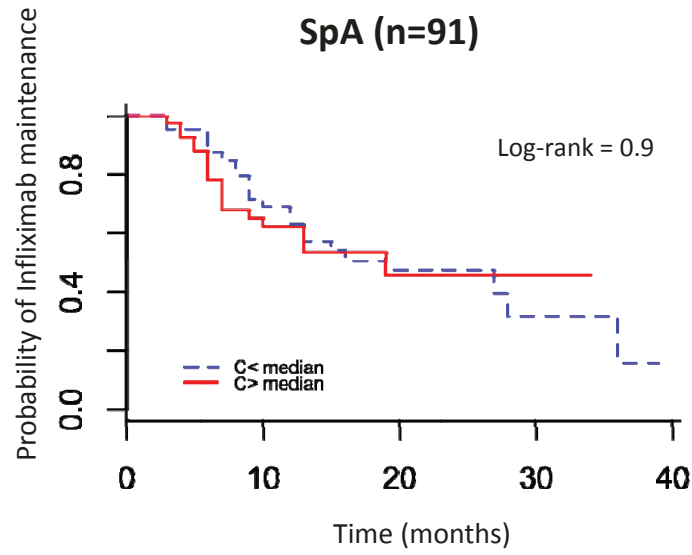

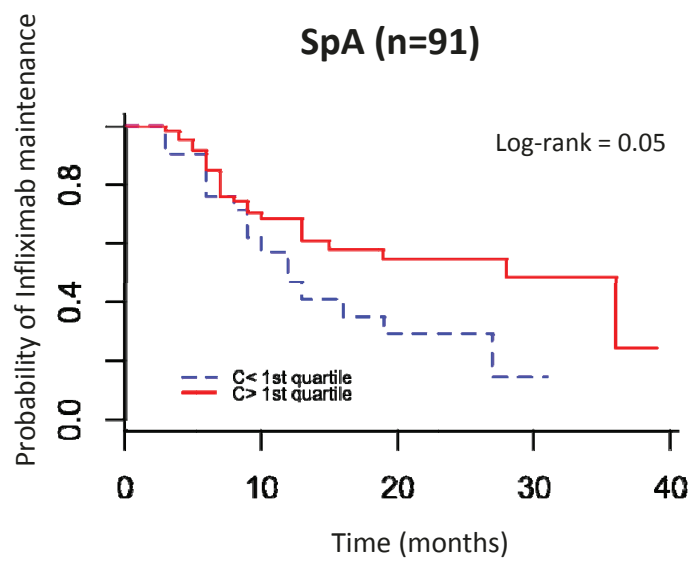

Figure 4 Maintenance of treatment by trough infliximab concentration after treatment initiation. RA patients were separated according to (a) the median and (b) the first quartile of trough infliximab concentrations measured at week 14. SpA patients were separated according to the (a) median and (b) the first quartile of trough infliximab concentrations measured at week 14. RA: rheumatoid arthritis; SpA:

spondyloarthritis.

definite conclusions. To our knowledge, the present study provides the first evidence of a significant association of the use of MTX and a reduced risk of ATI development in SpA. Breban et al. [17] tested MTX in combination with infliximab in a subset of ankylosing spondylitis patients receiving treatment with infliximab by using an on-demand strategy. They showed a trend toward fewer reactions to infusions in the group receiving MTX as compared with the group not receiving MTX, although these results were not statistically significant. The fact that none of our SpA patients with MTX have developed ATI suggests that MTX is a credible factor in reducing immunisation and should be given in combination with $\mathrm{mAb}$.

High trough infliximab concentrations measured at the end of treatment initiation (that is, before the fourth infusion) seem to predict infliximab maintenance in both RA and SpA. This result is in agreement with the findings of our previous reports and suggests that early monitoring and dosage adjustment of underexposed patients could improve long-term infliximab maintenance $[18,19]$.

\section{Conclusion}

In summary, almost $20 \%$ of patients with rheumatic diseases who received infliximab showed ATI during follow-up, half of them before four months after treatment initiation. High initial serum concentration of infliximab reduces the development of ATI, and absence of ATI seems to prolong maintenance of infliximab. Taken together, these findings argue for early monitoring of infliximab serum concentrations and should be confirmed in a prospective study. 


\section{Abbreviations}

ATI: antibody toward infliximab; BASDAI: Bath Ankylosing Spondylitis Disease Activity Index; CRP: C-reactive protein; ELISA: enzyme-linked immunosorbent assay; ESR: erythrocyte sedimentation rate; mAb: monoclonal antibody; MTX: methotrexate; RA: rheumatoid arthritis; SpA: spondyloarthritis; TNFa: tumour necrosis factor a.

\section{Acknowledgements}

The authors thank Françoise Gouais, Martine Creton, Marie-Françoise Coudray, Fabienne Chapacou, Dominique Guillon, Rodolphe Laurent, Patricia Pitault and Fabienne Georges for blood sampling and Anne-Claire Duveau for technical assistance in infliximab concentration measurements.

\section{Author details}

${ }^{1}$ Université François Rabelais de Tours, Centre National de la Recherche Scientifique UMR 6239 GICC (Génétique Immunothérapie Chimie et Cancer), 3 rue des Tanneurs, F-37041 Tours Cedex 1, France. ${ }^{2}$ Service de Rhumatologie, Centre Hospitalier Régional et Universitaire de Tours, avenue de la République, F-37044 Tours Cedex 9, France. ${ }^{3}$ Laboratoire de Pharmacologie-Toxicologie, Centre Hospitalier Régional et Universitaire de Tours, 2 boulevard Tonnellé, F-37044 Tours Cedex 9, France. ${ }^{4}$ Laboratoire d'Immunologie, Centre Hospitalier Régional et Universitaire de Tours, 2 boulevard Tonnellé, F-37044 Tours Cedex 9, France.

\section{Authors' contributions}

ED and DM drafted the manuscript, supervised the study design and performed the statistical analysis. GP and PG helped draft the manuscript. DT and HW supervised the immunoassays. DCML and FL performed clinical measurements. All authors approved the final manuscript.

\section{Competing interests}

$\mathrm{ED}, \mathrm{DCML}, \mathrm{FL}$, DT and HW have no competing interests to declare. DM received grant/research support from Abbott Laboratories. GP is a consultant for Laboratoires Français du Fractionnement et des Biotechnologies, Roche and Wyeth. PG received grant/research support from Abbott Laboratories, Schering-Plough, Wyeth, Roche and Bristol-Myers Squibb and is a consultant for Laboratoires Français du Fractionnement et des Biotechnologies, Roche, Schering-Plough and Wyeth.

Received: 4 March 2011 Revised: 3 June 2011 Accepted: 27 June 2011 Published: 27 June 2011

\section{References}

1. Maini RN, Breedveld FC, Kalden JR, Smolen JS, Davis D, Macfarlane JD, Antoni C, Leeb B, Elliott MJ, Woody JN, Schaible TF, Feldmann M: Therapeutic efficacy of multiple intravenous infusions of anti-tumor necrosis factor a monoclonal antibody combined with low-dose weekly methotrexate in rheumatoid arthritis. Arthritis Rheum 1998, 41:1552-1563.

2. Braun J, Brandt J, Listing J, Zink A, Alten R, Burmester G, Golder W, Gromnica-Ihle E, Kellner H, Schneider M, Sörensen H, Zeidler H, Reddig J, Sieper J: Long-term efficacy and safety of infliximab in the treatment of ankylosing spondylitis: an open, observational, extension study of a three-month, randomized, placebo-controlled trial. Arthritis Rheum 2003, 48:2224-2233.

3. van der Heijde D, Dijkmans B, Geusens P, Sieper J, DeWoody K, Williamson P, Braun J, Ankylosing Spondylitis Study for the Evaluation of Recombinant Infliximab Therapy Study Group: Efficacy and safety of infliximab in patients with ankylosing spondylitis: results of a randomized, placebo-controlled trial (ASSERT). Arthritis Rheum 2005, 52:582-591.

4. Bendtzen K, Geborek P, Svenson M, Larsson L, Kapetanovic MC, Saxne T: Individualized monitoring of drug bioavailability and immunogenicity in rheumatoid arthritis patients treated with the tumor necrosis factor a inhibitor infliximab. Arthritis Rheum 2006, 54:3782-3789.

5. Wolbink GJ, Vis M, Lems W, Voskuyl AE, de Groot E, Nurmohamed MT, Stapel S, Tak PP, Aarden L, Dijkmans B: Development of antiinfliximab antibodies and relationship to clinical response in patients with rheumatoid arthritis. Arthritis Rheum 2006, 54:711-715.

6. de Vries MK, Wolbink GJ, Stapel SO, de Vrieze H, van Denderen JC, Dijkmans BA, Aarden LA, van der Horst-Bruinsma IE: Decreased clinical response to infliximab in ankylosing spondylitis is correlated with antiinfliximab formation. Ann Rheum Dis 2007, 66:1252-1254.

7. Krzysiek R, Breban M, Ravaud P, Prejean MV, Wijdenes J, Roy C, Henry YD, Barbey C, Trappe G, Dougados M, Emilie D, French Ankylosing Spondylitis Infliximab Network: Circulating concentration of infliximab and response to treatment in ankylosing spondylitis: results from a randomized control study. Arthritis Rheum 2009, 61:569-576.

8. Fautrel B, Pham T, Mouterde G, Le Loët X, Goupille P, Guillemin F, Ravaud P, Cantagrel A, Dougados M, Puéchal X, Sibilia J, Soubrier M, Mariette X, Combe B, Club Rhumatismes et Inflammation, Société Française de Rhumatologie: Recommendations of the French Society for Rheumatology regarding TNFa antagonist therapy in patients with rheumatoid arthritis. Joint Bone Spine 2007, 74:627-637.

9. Pham T, Fautrel B, Dernis E, Goupille P, Guillemin F, Le Loët X, Ravaud P, Claudepierre P, Miceli-Richard C, de Bandt M, Breban M, Maillefert JF, Masson C, Saraux A, Schaeverbeke T, Wendling D, Mariette X, Combe B, Club Rhumatismes et Inflammation (CRI/SFR): Recommendations of the French Society for Rheumatology regarding TNFa antagonist therapy in patients with ankylosing spondylitis or psoriatic arthritis: 2007 update. Joint Bone Spine 2007, 74:638-646.

10. Ternant D, Mulleman D, Degenne D, Willot S, Guillaumin JM, Watier H, Goupille P, Paintaud G: An enzyme-linked immunosorbent assay for therapeutic drug monitoring of infliximab. Ther Drug Monit 2006, 28:169-174.

11. Van Assche G, Magdelaine-Beuzelin C, D'Haens G, Baert F, Noman M, Vermeire S, Ternant D, Watier H, Paintaud G, Rutgeerts P: Withdrawal of immunosuppression in Crohn's disease treated with scheduled infliximab maintenance: a randomized trial. Gastroenterology 2008, 134:1861-1868.

12. Mulleman D, Méric JC, Paintaud G, Ducourau E, Magdelaine-Beuzelin C, Valat JP, Goupille P, Centre National de la Recherche Scientifique UMR 6239 GICC: Infliximab concentration monitoring improves the control of disease activity in rheumatoid arthritis. Arthritis Res Ther 2009, 11:R178.

13. The R Project for Statistical Computing. [http://www.R-project.org/].

14. Xu Z, Seitz K, Fasanmade A, Ford J, Williamson P, Xu W, Davis HM, Zhou H: Population pharmacokinetics of infliximab in patients with ankylosing spondylitis. J Clin Pharmacol 2008, 48:681-695

15. Ternant D, Aubourg A, Magdelaine-Beuzelin C, Degenne D, Watier H, Picon L, Paintaud G: Infliximab pharmacokinetics in inflammatory bowel disease patients. Ther Drug Monit 2008, 30:523-529.

16. Bartelds GM, Krieckaert CL, Nurmohamed MT, van Schouwenburg PA, Lems WF, Twisk JW, Dijkmans BA, Aarden L, Wolbink GJ: Development of antidrug antibodies against adalimumab and association with disease activity and treatment failure during long-term follow-up. JAMA 2011, 305:1460-1468.

17. Breban M, Ravaud P, Claudepierre P, Baron G, Henry YD, Hudry C, EullerZiegler L, Pham T, Solau-Gervais E, Chary-Valckenaere I, Perdriger A, Le Loët $X$, Wendling D, Fautrel B, Fournié B, Combe B, Gaudin P, Jousse $S$, Mariette X, Baleydier A, Trape G, Dougados M, French Ankylosing Spondylitis Infliximab Network: Maintenance of infliximab treatment in ankylosing spondylitis: results of a one-year randomized controlled trial comparing systematic versus on-demand treatment. Arthritis Rheum 2008, 58:88-97.

18. Mulleman D, Chu Miow Lin D, Ducourau E, Emond P, Ternant D, Magdelaine-Beuzelin C, Valat JP, Paintaud G, Goupille P: Trough infliximab concentrations predict efficacy and sustained control of disease activity in rheumatoid arthritis. Ther Drug Monit 2010, 32:232-236.

19. Chu Miow Lin D, Mulleman D, Azzopardi N, Griffoul-Espitalier I, Valat JP, Paintaud G, Goupille P: Trough infliximab concentration may predict long-term maintenance of infliximab in ankylosing spondylitis. Scand J Rheumatol 2010, 39:97-98.

\section{doi:10.1186/ar3386}

Cite this article as: Ducourau et al: Antibodies toward infliximab are associated with low infliximab concentration at treatment initiation and poor infliximab maintenance in rheumatic diseases. Arthritis Research \& Therapy 2011 13:R105. 